\title{
PENGARUH KARAKTERISTIK PERUSAHAAN DAN PROFITABILITAS TERHADAP KELENGKAPAN PENGUNGKAPAN SUKARELA DALAM \\ LAPORAN TAHUNAN \\ (Studi Empiris Pada Perusahaan Perbankan Yang Terdaftar Di Bursa Efek Indonesia Periode 2015-2018)
}

Futry Dwi Jayanti ${ }^{1}$

Futryjayanti@gmail.com

Sylvia C. Daat SE., M.Sc., Ak., CA ${ }^{2}$

Hastutie Noor Andriati, SE., M.Si., Ak., $\mathrm{CA}^{3}$

Jurusan Akuntansi, Fakultas Ekonomi dan Bisnis Universitas Cenderawasih

\begin{abstract}
This study aims to provide empirical evidence about the effect of company size, listing age, capital adequacy ratio, non-performing loans and profitability on voluntary disclosure. This study uses the independent variable size of the company, age of listing, capital adequacy ratio $(C A R)$, non-performing loan (NPL) and profitability and the dependent variable is voluntary disclosure. The sample used in this study is the annual report of banking companies registered in 2015-2018 on the Indonesia Stock Exchange. Select 30 banking companies with purposive sampling. Data collection techniques are documentation, book reviews and literature. And the data analysis technique is multiple linear regression, which consists of descriptive statistical analysis, classic assumption test: normality, multicollinearity, autocorrelation, heteroscedasticity, and hypothesis testing. The results of the analysis show that all independent variables have a simultaneous significant influence on the level of completeness of voluntary disclosure. Then, company size, listing age significantly affect the level of completeness of voluntary disclosure. Conversely, the capital adequacy ratio (CAR), non-performing loan (NPL) and profitability do not have a significant effect on the level of completeness of voluntary disclosure.
\end{abstract}

Keywords $\quad$ : company characteristics, capital adequacy ratio, non-performing loans, profitability, voluntary disclosure

\section{PENDAHULUAN}

Pada era globalisasi saat ini menuntut adanya suatu standar akuntansi keuangan yang dapat diberlakukan secara internasional di setiap negara, sehingga menghasilkan informasi keuangan yang dapat diperbandingkan. Bank merupakan jantung perekonomian suatu Negara, kemajuan perekonomian suatu negara dapat diukur dari kemajuan bank di negara tersebut. Mengingat besarnya pengaruh bank terhadap perekonomian suatu negara bukan berarti bank tidak mempunyai kendala ataupun masalah. Salah satu masalah yang dihadapi perbankan adalah masalah kinerja bank dalam mengungkapkan informasi. Dalam hal ini tingkat informasi yang dapat diperoleh akan sangat tergantung pada sejauh mana tingkat pengungkapan (disclosure) dari perusahaan yang bersangkutan.

Melalui pengungkapan (disclosure) manajemen menyampaikan informasi mengenai kondisi yang diberikan oleh perusahaan melalui pengungkapan harus sesuai dengan standar pengungkapan yang di tentukan serta jelas dan lengkap. pengungkapan sukarela menjadi salah satu alat yang dapat membantu para investor dalam memahami strategi bisnis perusahaan juga menjadi alat untuk membantu manajemen dalam meningkatkan kredibilitas guna melengkapi strategi pelaporan dan

\footnotetext{
${ }^{1}$ Alumni Jurusan Akuntansi FEB Uncen

${ }^{2}$ Dosen Jurusan Akuntansi FEB Uncen

3 Dosen Jurusan Akuntansi FEB Uncen
} 
pengungkapan perusahaan.

Beberapa penelitian yang menganalisis pengaruh karakteristik perusahaan terhadap pengungkapan dalam laporan tahunan memberikan hasil yang konsisten, namun beberapa diantaranya memberikan hasil yang belum konsisten. Penelitian (Suta, 2012); (Nuryaman, 2014) meneliti mengenai pengaruh karakteristik perusahaan terahadap pengungkapan dalam annual report. Hasil dari penelitian ini membuktikan bahwa variabel yang konsisten berpengaruh adalah ukuran perusahaan yang merupakan karakteristik perusahaan. Sedangkan karakteristik yang lain dalam penelitian ini tidak menunjukkan kekonsistenan.

Berdasarkan permasalahan yang dikemukakan diatas, dapat diajukan pertanyaan penelitian sebagai berikut : a) Apakah ukuran perusahaan berpengaruh terhadap tingkat kelengkapan pengungkapan sukarela dalam laporan tahunan perbankan; b) Apakah umur listing berpengaruh terhadap tingkat kelengkapan pengungkapan sukarela dalam laporan tahunan perbankan ; c) Apakah Capital Adequacy Ratio (CAR) berpengaruh terhadap tingkat kelengkapan pengungkapan sukarela dalam laporan tahunan perbankan ? ; d) Apakah Non Performing Loan (NPL) berpengaruh terhadap tingkat kelengkapan pengungkapan sukarela dalam laporan tahunan perbankan ? e) Apakah profitabilitas berpengaruh terhadap tingkat kelengkapan pengungkapan sukarela dalam laporan tahunan perbankan.

Adapun yang menjadi tujuan dari penelitian ini guna memperoleh bukti empiris tentang pengaruh dari ukuran perusahaan, umur listing, Capital Adequacy Ratio (CAR), Non Performing Loan (NPL) dan profitabilitas terhadap tingkat pengungkapan sukarela dalam laporan tahunan perbankan di Indonesia.

\section{TINJAUAN PUSTAKA}

\subsection{Teori Pensinyalan (Signaling Theory)}

Teori pensinyalan membahas mengenai dorongan perusahaan untnuk memberikan informasi kepada pihak eksternal. Pensinyalan juga dapat dilakukan perusahaan pada laporan tahunannya dengan memberikan informasi yang lengkap dan transparan. Hal ini dapat memberikan sinyal positif dari perusahaan kepada stakeholder yang dapat berpengaruh terhadap keputusan bisnis yang akan diambil. Dalam hal pengungkapan informasi yang bersifat sukarela. Transparansi tersebut dapat menyebabkan para stakeholder mendapatkan informasi yang lebih baik dan akan mengurangi potensi terjadi asimetri informasi. Pengungkapan informasi sukarela (voluntary disclosure) dalam laporan tahunan perusahaan dapat memberikan sinyal positif bahwa perusahaan memberikan informasi yang lebih rinci dan lebih luas yang tidak terdapat pada laporan keuangan.

\subsection{Teori Stakeholder}

Teori lain yang mendukung penelitian ini adalah teori stakeholder. Organisasi atau perusahaan tentunya tidak dapat berdiri sendiri, pasti berhubungan dengan banyak pihak, yang disebut sebagai stakeholder. Teori stakeholder menjelaskan bahwa perusahaan bukan entitas yang hanya beroperasi untuk kepentingannya sendiri, namun harus memberikan manfaat bagi stakeholder.

\subsection{Pengungkapan Sukarela (Voluntary Disclosure)}

Pengungkapan (disclosure) adalah informasi yang diberikan oleh perusahaan kepada pihak-pihak yang berkepentingan mengenai keadaan perusahaan. Pengungkapan dapat diartikan sebagai pengeluaran informasi yang disajikan dalam laporan keuangan. Luas pengungkapan laporan keuangan mencerminkan kualitas informasi yang disajikan oleh perusahaan, terutama yang berkaitan dengan kondisi keuangan yang disajikan oleh perusahaan dan yang berkaitan dengan kondisi keuangan perusahaan (Widianto, 2011). Artinya semakin luas pengungkapan yang dilakukan oleh suatu perusahaan akan meningkatkan kualitas informasi yang mungkin akan didapat oleh pengguna laporan keuangan terutama yang berhubungan dengan kondisi keuangan suatu perusahaan. 


\subsection{Ukuran Perusahaan}

Ukuran perusahaan menunjukkan besar kecilnya perusahaaan dan struktur kepemilikan yang dimilikinya. Ukuran bank menunjukkan skala usaha yang dilakukan oleh bank yang terlihat dari jumlah aset atau aktiva bank, bertambahnya aktiva bank menunjukkan bertambah besar investasi yang dilakukan.

\subsection{Umur Listing}

Umur listing perusahaan merupakan seberapa lama perusahaan terdaftar di Bursa Efek Indonesia (BEI) sebagai perusahaan go public. Semakin panjang umur listing perusahaan akan memberikan pengungkapan lebih luas dibandingkan perusahaan lain terutama perusahaan perbankan yang umumnya lebih pendek dengan alasan perusahaan tersebut memiliki pengungkapan laporan tahunan (annual report) dengan pengalaman lebih dalam.

\subsection{Capital Adequacy Ratio (CAR)}

Capital Adequacy Ratio (CAR) adalah kemampuan bank dalam mempertahankan modal yang mencukupi dan kemampuan manajemen bank dalam mengidentifikasi, mengukur, mengawasi dan mengontrol risiko-risiko yang timbul yang dapat berpengaruh terhadap besarnya modal bank.

CAR adalah rasio yang memperlihatkan seberapa jauh seluruh aktiva bank yang mengandung risiko (kredit, penyertaan, surat berharga, tagihan pada bank lain) ikut dibiayai dari dana modal sendiri bank di samping memperoleh dana-dana dari sumber di luar bank, seperti dana masyarakat, pinjaman (utang), dan lain-lain. Dengan kata lain, capital adequacy ratio adalah rasio kinerja bank untuk mengukur kecukupan modal yang dimiliki bank untuk menunjang aktiva yang mengandung atau menghasilkan risiko, misalnya kredit yang diberikan.

\subsection{Non Performing Loan (NPL)}

Non Performing Loan (NPL) adalah kredit yang menunggak melebihi 90 hari, di mana NPL maka semakin besar risiko kredit yang ditanggung oleh pihak bank. Rasio NPL merupakan proksi dari risiko kredit yang terdapat dalam laporan keuangan publikasi. Bank dapat menjalankan operasinya dengan baik jika mempunyai NPL dibawah $5 \%$.

Kenaikan NPL yang semakin tinggi menyebabkan cadangan yang ada tidak mencukupi sehingga pemacetan kredit harus diperhitungkan sebagai beban (biaya) yang langsung berpengaruh terhadap keuangan bank karena keuntungan atau akumulasi keuntungan juga akan habis, maka harus dibebankan kepada modal. Kenaikan mengakibatkan laba menurun sehingga kesempatan mendapatkan keuntungan dalam investasi menjadi semakin kecil.

\subsection{Profitabilitas}

Profitabilitas berhubungan dengan kemampuan suatu perusahaan khususnya sektor perbankan untuk menyediakan reward keuangan yang cukup utuk memberikan daya tarik dan menjaga pendanaan perusahaan, sehingga semakin tinggi profitabilitas, maka kelangsungan usaha perusahaan juga semakin terjaga.

Adapun penelitian yang dilakukan oleh (Achmad, 2012) yaitu tentang pengaruh corporate governance dari karakteristik perusahaan terhadap luas pengungkapan informasi sukarela. Pengungkapan sukarela menjadi variabel dependen dan yang menjadi variabel independen adalah dewan komisaris, ukuran perusahaan, leverage dan profitablitas. Hasil dari penelitian ini membuktikan bahwa dewan komisaris, ukuran perusah perusahaan dan profitabilitas berhubungan signifikan dengan arah positif terhadap luas pengungkapan sukarela. Sedangkan leverage berhubungan siginifikan negatif.

\subsection{Penelitian Terdahulu dan Pengembangan Hipotesis}

\subsubsection{Ukuran Perusahaan Terhadap Tingkat Kelengkapan Pengungkapan Sukarela (Voluntary}

\section{Disclosure)}

Ukuran perusahaan menunjukkan besar kecilnya suatu perusahaan. Ukuran perusahaan tersebut juga menujukkan banyak sedikitnya aset yang dimiliki suatu perusahaan. Selain itu, ukuran perusahaan juga merupakan salah satu faktor yang menentukan kemampuan perusahan dalam menghasilkan laba. 
Semakin besar perusahaan biasanya mereka mempunyai kekuatan tersendiri dalam menghadapi masalh bisnis. Semakin besar juga ukuran perusahaan maka semakin banyak juga pengungkapan yang dilakukannya oleh manajemen sebagai pemenuh informasi bagi para stakeholder.

Penelitian pertama tentang pengungkapan sukarela yang dilakukan oleh (Suripto, 1999) mengenai pengaruh karakteristik perusahaan terhadap luas pengungkapan sukarela dalam laporan tahunan. Salah satu variabel yang mempengaruhi tingkat pengungkapan sukarela dalam laoran tahunan adalah ukuran perusahaan. Penelitian yang dilakukan oleh (Suripto, 1999) telah membuktikan bahwa keseluruhan variabel independen secara bersama-sama mampu menjelaskan variansi keluasan pengungkapan sukarela di dalam laporan tahunan. Tetapi secara individu, hanya ukuran perusahaan dan rencana perusahaan untuk menerbitkan sekuritas pada tahun-tahun berikutnya yang mempengaruhi pengungkapan sukarela secara signifikan.

Adapun penelitian yang dilakukan oleh (Wardani, 2012) menggunakan ukuran perusahaan sebagai variabel yang sering digunakan dalam meneliti luas pengungkapan dan hasilnya ukuran perusahaan berpengaruh positif dengan luas pengungkapan yang dilakukan oleh sebuah perusahaan.

Artinya semakin besar perusahaan, akan semakin luas pula pengungkapan yang dilakukan perusahaan. Wardani (2012) menyatakan bahwa tingkat keluasan informasi dalam kebijakan pengungkapan perusahaan akan meningkat seiring dengan meningkatnya ukuran perusahaan, hal ini dikarenakan suatu perusahaan yang berukuran lebih besar cenderung memiliki tuntutan publik (public demand) akan informasi yang lebih tinggi dibanding dengan perusahaan yang berukuran kecil.

Besar-kecil ukuran perusahaan dapat dilihat dari seluruh aset yang dimiliki oleh perusahaan tersebut, karena aset yang dimiliki suatu perusahaan mencerminkan sumber daya yang dimiliki oleh perusahaan tersebut untuk dapat melakukan kegiatan operasionalnya untuk menghasilkan suatu output. Untuk penelitian ini proksi ukuran perusahaan berdasarkan pada penelitian yang dilakukan Wardani (2012) dan akan memanfaatkan ukuran total aset atau aktiva yang dimiliki sebuah perusahaan.

Berdasarkan teori dan hasil penelitian terdahulu, maka hipotesis pertama penelitian ini, sebagai berikut:

\section{H1 : Ukuran Perusahaan Berpengaruh Terhadap Tingkat Kelengkapan} Pengungkapan Sukarela.

\subsubsection{Umur Listing Terhadap Tingkat Kelengkapan Pengungkapan Sukarela (Voluntary Disclosure)}

Umur listing perusahaan merupakan lamanya perusahaan terdaftar di BEI (Bursa Efek Indonesia) untuk perusahaan go public. Semaking panjang suatu umur listing perusahaan akan memberikan pengungkapan lebih luas di bandingkan perusahaan lain yang umurnya lebih pendek dengan alasan perusahaan tersebut memiliki pengungkapan laporan tahunan (annual report) dengan pengalaman lebih dalam. Semakin lama perusahaan menjadi perusahaan publik, maka diharapkan perusahaan semakin mengetahui kebutuhan informasi para penggunanya atau semakin mengetahui kebutuhan informasi para stakeholder perusahaan.

Marwoto (2013) menjelaskan bahwa umur perusahaan berpengaruh positif terhadap luas pengungkapan sukarela perusahaan. Hal ini dikarenakan, perusahaan yang memiliki umur lebih lama memiliki pengalaman yang lebih banyak dalam mempublikasi laporan tahunan (Sembiring, 2014). Proksi yang digunakan dalam umur listing perusahaan yakni dengan cara mencari selisih antara tahun sekarang dengan tahun awal perusahaan listing pada BEI (Bursa Efek Indonesia).

Penelitian yang dilakukan oleh Wardani (2012) menguji pengaruh umur listing perusahaan terhadap luas pengungkapan sukarela pada perusahaan sektor rill yang terdaftar di Bursa Efek Indonesia tahun 2010 yang menyimpulkan bahwa umur perusahaan berpengaruh terhadap luas pengungkapan sukarela perusahaan, namun pengaruhnya menunjukkan arah yang negatif. Artinya, semakin lama suatu perusahaan terdaftar di Bursa Efek Indonesia, maka akan semakin sedikit 
pengungkapan sukarela yang dilakukan oleh perusahaan.

Berdasarkan teori dan hasil penelitian terdahulu, maka hipotesis ketiga penelitian ini, sebagai berikut:

H2 : Umur Listing Berpengaruh Terhadap Tingkat Kelengkapan Pengungkapan Sukarela.

\subsubsection{Capital Adequacy Ratio (CAR) Terhadap Tingkat Kelengkapan Pengungkapan Sukarela (Voluntary Disclosure)}

Capital Adequacy Ratio adalah rasio yang memperlihatkan seberapa besar jumlah seluruh aktiva bank yang mengandung unsur risiko (kredit, penyertaan, surat berharga, tagihan pada bank lain) yang ikut dibiayai dari modal sendiri pada perusahaan perbankan, disamping memperoleh suatu dana-dana dari sumber-sumber diluar bank (Dendawijaya, 2012).

Capital Adequacy Ratio (CAR) yang tinggi berarti bank mempunyai kemampuan untuk mengatasi kemungkinan kerugian akibat perkreditan dan percaya terhadap kemampuan permodalan bank dan dana yang diserap dari masyarakat meningkat yang akhirnya akan meningkatkan laba perusahaan.

Hasil Penelitian yang telah ada menyatakan bahwa Capital Adequacy ratio (CAR) merupakan rasio kecukupan modal pada bank yang di mana pengungkapan sukarela tidak dapat mengubah besar kecil modal yang diperoleh bank, hal ini diduga karena bank pasti akan lebih fokus kepada nasabah dan pemegang saham. Kemudian modal tersebut lebih berpengaruh pada pembiayaan atau pemberian kredit atau biaya operasional bank tersebut, sehingga bank tidak begitu berfokus pada pengungkapan sukarela dengan menggunakan modalnya.

Hasil penelitian lain Masrurroh (2017) menyatakan bahwa hal ini di duga karena pada awal menerapkan CSR bank sudah siap dengan dana khusus untuk CSR, namun tahun selanjutnya kekurangan modal untuk dialokasikan pada program CSR. Seharusnya manajemen bank harus lebih kreatif lagi dalam menentukan program CSR untuk masyarakat supaya dalam mengungkapkan CSR di annual report dapat menarik para investor atau mitra untuk membantu program CSR pada bank tersebut. Khususnya membantu dana untuk melancarkan program CSR kepada masyarakat agar programnya lebih baik dan berkualitas.

Berdasarkan teori dan hasil penelitian terdahulu, maka hipotesis keempat penelitian ini, sebagai berikut:

H3 : Capital Adequacy Ratio Berpengaruh Terhadap Tingkat Kelengkapan Pengungkapan Sukarela.

\subsubsection{Non Performing Loan Terhadap Tingkat Kelengkapan Pengungkapan Sukarela (Voluntary Disclosure)}

Non Performing Loan (NPL) adalah perbandingan antara total kredit bermasalah dengan total kredit yang diberikan kepada debitur. Bank dikatakan mempunyai NPL (Non Performing Loan) yang tinggi jika banyaknya kredit yang bermasalah lebih besar dari pada jumlah kredit yang diberikan kepada debitur. Apabila suatu bank mempunyai NPL (Non Performing Loan) yang tinggi, maka akan memperbesar biaya, baik biaya pencadangan aktiva produktif maupun biaya lainnya, dengan kata lain semakin tinggi NPL suatu bank, maka hal tersebut akan mengganggu kinerja bank tersebut. Namun, Non Performing Loan (NPL) yang tinggi mencerminkan banyaknya kredit bermasalah dibandingkan dengan jumlah kredit yang diberikan, dimana hal tersebut akan mengganggu kinerja bank tersebut (Marurroh, 2017).

Semakin besar tingkat NPL maka menunjukkan bahwa bank tersebut tidak professional dalam pengelolaan kreditnya dan memberikan indikasi bahwa risiko atas pemberian kredit pada bank cukup searah dengan tingginya NPL yang dihadapi oeh bank. Dengan demikian, tinggi atau rendanya NPL tidak berpengaruh pada pengungkapan CSR. Penerapan dan pengungkapan CSR bukan lagi sekedar kegiatan melainkan sebuah kewajiban bagi bank syariah dalam menjaga kelangsungan hidupnya. 
Maka, tinggi rendahnya NPL (Non Performing Loan) tidak menghalangi bank melakukan kegiatan CSR karena memang sudah kewajiban bank untuk memperhatikan kondisi masyarakat di sekitar bank tersebut. Maka NPL (Non Performing Loan) pada bank tidak berpengaruh terhadap pengungkapan CSR.

H4 : Non Performing Loan Berpengaruh Terhadap Tingkat Kelengkapan Pengungkapan Sukarela.

\subsubsection{Profitabilitas Berpengaruh Terhadap Tingkat Kelengkapan Pengungkapan Sukarela (Voluntary Disclosure)}

Profitabilitas berhubungan dengan kemampuan suatu perusahaan untuk menyediakan reward keuangan yang cukup untuk memberikan daya tarik dan menjaga pendanaan perusahaan (Sudarmadji \& Sularto, 2012) sehingga semakin tinggi suatu profitabilitas, maka kelangsungan upaya perusahaan juga semakin terjaga. Informasi mengenai profitabilitas dan likuiditas perusahaan diperlukan oleh stakeholders untuk mengawasi kinerja suatu manajemen yang diungkapkan oleh perusahaan melalui laporan tahunannya untuk menganalisis kelangsungan upaya perusahaan. Selain beberapa faktor di atas, umur suatu perusahaan dapat pula menentukan kelangsungan usaha perusahaan.

Menurut Wardani (2012), rentabilitas ekonomi dan profit margin yang tinggi akan mendorong para manajer untuk memberikan informasi yang lebih rinci untuk menggambarkan kemampuan memaksimalkan nilai pemegang saham dan meningkatkan kompensasi manajemen. Manajer dari sebuah perusahan yang memiliki rasio profitabilitas tinggi akan merasa bangga dengan hasil pencapainannya, sehingga cenderung untuk mengungkapkan lebih banyak informasi untuk memberikan kesan positif kinerja yang dicapainya dengan harapan mendapatkan timbal balik berupa peningkatan kompensasi.

Adapun penelitian yang dilakukan oleh (Achmad, 2012) yaitu tentang pengaruh corporate governance dari karakteristik perusahaan terhadap luas pengungkapan informasi sukarela. Pengungkapan sukarela menjadi variabel dependen dan yang menjadi variabel independen adalah dewan komisaris, ukuran perusahaan, leverage dan profitablitas. Hasil dari penelitian ini membuktikan bahwa dewan komisaris, ukuran perusah perusahaan dan profitabilitas berhubungan signifikan dengan arah positif terhadap luas pengungkapan sukarela. Sedangkan leverage berhubungan siginifikan negatif.

Berdasarkan teori dan hasil penelitian terdahulu, maka hipotesis kedua penelitian ini, sebagai berikut:

H5 : Profitabilitas Berpengaruh Terhadap Tingkat Kelengkapan Pengungkapan Sukarela.

\subsection{Model Penelitian}

Dari pemaparan diatas dapat dibuat kaitan antara ukuran perusahaan, umur listing, capital adequacy ratio, non performing loan dan profitabilitas terhadap tingkat pengungkapan sukarela dengan model penelitian pada gambar berikut ini : 
Model Penelitian

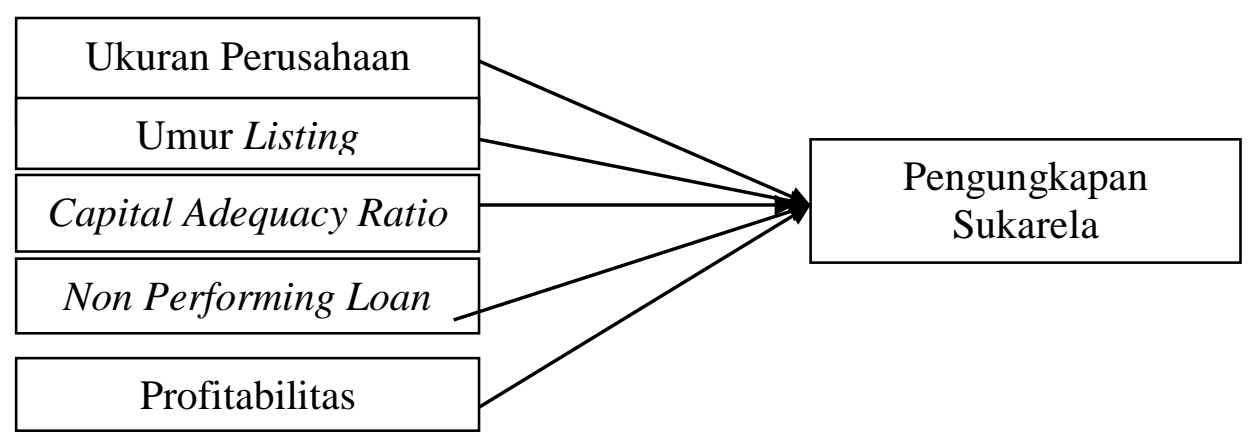

Sumber : Penulis 2019

\section{METODE PENELITIAN}

\subsection{Jenis dan Sumber Data}

Jenis data yang digunakan dalam penelitian ini adalah data sekunder, yaitu data yang diperoleh secara tidak langsung melalui media perantara (diperoleh dan dicatat oleh pihak lain). Data sekunder yang digunakan merupakan data time series berupa daftar dari data laporan tahunan perusahaan sektor perbankan yang terdaftar di Bursa Efek Indonesia tahun 2015-2018.

\subsection{Populasi dan Sampel}

Populasi dalam penelitian ini adalah sektor perusahaan perbankan yang telah terdaftar Di Bursa Efek Indonesia (BEI) tahun 2015-2018. Sampel dalam penelitian ini merupakan sektor perusahaan perbankan yang terdaftar di Bursa Efek Indonesia (BEI) pada tahun 2015-2018. Pengambilan sampel yang dilakukan dalam penelitian ini menggunakan metode purposive sampling dengan kriteria sebagai berikut :

1. Sumber data yang digunakan dalam penelitian ini adalah yang telah dipublikasikan pada tahun 2015-2018 oleh perusahaan-perusahaan yang terdaftar di Bursa Efek Indonesia (BEI) yaitu www.idx.co.id.

2. Memiliki laporan tahunan yang lengkap.

3. Menyajikan laporan tahunan dalam mata uang rupiah.

4. Perusahaan perbankan yang memperoleh laba positif selama periode tahun 2015-2018.

Pengambilan sampel pada periode 2015-2018 didasarkan karena penelitian ini memperoleh informasi terkini mengenai karakteristik perusahaan dan profitabilitas terhadap tingkat pengungkapan sukarela dalam laporan tahunan perusahaan sektor perbankan di Indonesia. Laporan tahunan menjadi salah satu sumber informasi bagi investor untuk pengambilan keputusan dalam melakukan investasi.

\subsection{Variabel Penelitian dan Pengukurannya}

Variabel dependen dalam penelitian ini adalah kelengkapan pengungkapan informasi sukarela (voluntary disclosure) dalam laporan tahunan. Menurut Wallace (dalam Andi Kartika, 2009), semakin banyak butir yang diungkap oleh perusahaan, semakin banyak pula angka indeks yang diperoleh perusahaan tersebut. Perusahaan dengan angka indeks yang lebih tinggi menunjukan bahwa perusahaan tersebut melakukan prakter pengungkapan secara lebih komprehensif relatif dibandingkan dengan perusahaan lain.

Untuk mengukur kelengkapan pengungkapan dapat dinyatakan dalam bentuk Indeks Kelengkapan Pengungkapan, dimana perhitungan Indeks Kelengkapan Pengungkapan dilakukan dengan cara : 
a. Memberi skor untuk setiap item pengungkapansecara dikotomi, dimana jika suatu item diungkapkan diberi nilai satu dan jika tidak diungkapkan akan diberi nilai nol.

b. Skor yang diperoleh setiap perusahaan dijumlahkan untuk mendapatkan skor total dan,

c. Menghitung Indeks Kelengkapan Pengungkapan dengan cara membagi total skor yang diperoleh dengan total skot yang diharapkan dapat diperoleh oleh perusahaan.

Menurut Sudarmadji dan Sularto (2007), instrumen pengukuran yang digunakan adalah itemitem voluntary disclosure yang dikembangkan oleh Suripto (1998) sebanyak 33 item. Perhitungan untuk angka indeks adalah sebagai berikut:

Indeks $=\mathrm{n} / \mathrm{k}$

Keterangan:

$\mathrm{n}=$ Jumlah butir pengungkapan sukarela yang terpenuhi

$\mathrm{K}=$ Jumlah semua butir pengungkapan sukarela yang mungkin dipenuhi

Wulansari (2008) mengatakan bahwa size atau ukuran perusahaan dapat diukur dengan jumlah aktiva yang dimiliki oleh perusahaan. Ukuran perusahaan dalam penelitian ini diukur berdasarkan penelitian Benardi, dkk (2009), yaitu dengan cara mengukur total aset dalam perusahaan. Pada penelitian ini Umur listing perusahaan akan diukur dengan cara menyelisihkan tahun bersangkutan yaitu tahun 2015, 2016, 2017 dan 2018 dengan tahun listing pertama perusahaan tersebut listing pada Bursa Efek Indonesia. Capital Adequacy Ratio (CAR) adalah rasio kecukupan modal atau kemampuan bank dalam permodalan guna menutup kerugian dalam perkreditan atau kemungkinan kerugian dalam perdagangan surat-surat berharga. Semakin tinggi CAR maka semakin baik kemampuan bank tersebut untuk menanggung risiko dari setiap kredit/aktiva produktif yang berisiko. Rasio CAR dapat dihitung dengan rumus modal dibagi asset tertimbang menurut resiko. Non Performing Loan (NPL) merupakan rasio keuangan yang menunjukkan risiko kredit yang dihadapi bank akibat pemberian kredit dan investasi dana bank pada portofolio yang berbeda. Rasio ini dapat diukur menggunakan rumus : kredit bermasalah di bagi total kredit. Besarnya profitabilitas diukur dengan rasio profit after tax terhadap total asset (Singhvi dan desai, 1971) yang dinamakan Return on Asset. ROA yang tinggi menandakan kemampuan perusahaan menghasilkan laba yang tinggi atas asset yang dimiliki.

\subsection{Metode Pengumpulan Data}

Metode pengumpulan data yang akan digunakan untuk dianalisis dalam penelitian ini adalah metode dokumentasi, karena data yang dikumpulkan adalah data sekunder dalam bentuk laporan keuangan perusahaan yang dijadikan subjek penelitian.

\subsection{Metode Analisis}

Dalam penelitian ini analisis regresi berganda digunakan untuk mengetahui ada atau tidaknya pengaruh variable independen terhadap veriabel dependen dengan rumus sebagai berikut:

$\mathrm{VDIS}=\mathrm{a}+\beta 1 \mathrm{SIZE}+\beta 2 \mathrm{LIST}+\beta 3 \mathrm{CAR}+\beta 4 \mathrm{NPL}+\beta 5 \mathrm{PROF}+\mathrm{e}$

Keterangan:

VDIS = Tingkat kelengkapan pengungkapan sukarela

$\mathrm{a}=$ Konstanta (constant)

$\beta 1-\beta 4=$ Koefisien regresi masing-masing variabel

SIZE $=$ Ukuran perusahaan

LIST = Umur listing perusahaan

CAR = Capital Adequacy Ratio

$\mathrm{NPL}=$ Non Performing Loan

PROF $=$ Profitabilitas

$\mathrm{e}=$ Error 


\section{HASIL PENELITIAN DAN PEMBAHASAN}

\subsection{Statistik Deskriptif}

Berdasarkan tabel dibawah, diketahui terdapat 5 variabel independen, yang diantaranya terdapat 120 sampel penelitian. Beberapa penjelasan mengenai hasil perhitungan statistik diuraikan sebagai berikut :

\section{Hasil Uji Deskriptif Statistik}

Descriptive Statistics

\begin{tabular}{|l|r|r|r|r|r|}
\hline & $\mathrm{N}$ & Minimum & Maximum & \multicolumn{1}{c|}{ Mean } & $\begin{array}{c}\text { Std. } \\
\text { Deviation }\end{array}$ \\
\hline VDIS & 120 &, 6061 &, 9697 &, 862118 &, 0794332 \\
SIZE & 120 & 28,3431 & 34,9434 & 31,501962 & 1,7781211 \\
LIST & 120 & 1,0000 & 36,0000 & 13,566667 & 8,9505958 \\
CAR & 120 &, 1033 &, 3821 &, 212405 &, 0479586 \\
NPL & 120 &, 0005 &, 0487 &, 017479 &, 0116813 \\
PROF & 120 &, 0013 &, 0785 &, 013040 &, 0099013 \\
Valid N & 120 & & & & \\
(listwise) & & & & & \\
\hline
\end{tabular}

Sumber : Data olahan SPSS

1) Pengungkapan Sukarela

Dari hasil pengujian statistik deskriptif rata-rata Pengungkapan Sukarela (VDIS) perusahaan perbankan di Indonesia pada tahun penelitian 2015-2018 adalah 0,862118 dengan standar deviasi 0,0794332. Dimana Pengungkapan Sukarela terendah adalah 0,6061 dan tertinggi adalah 0,9797 .

2) Ukuran Perusahaan

Dari hasil pengujian statistik deskriptif rata-rata ukuran perusahaan (SIZE) pada perusahaan perbankan di Indonesia tahun periode 2015-2018 adalah 31,501962 dengan standar deviasi 1,7781211. Dimana ukuran perusahaan terendah adalah 28,3431 dan tertinggi adalah 34,9434. Nilai tertinggi tersebut menunjukkan bahwa perusahaan sampel memiliki total aktiva tertinngi sebesar Rp 1.498.730.965.661.000.

3) Umur Listing

Dari hasil pengujian statistik deskriptif rata-rata umur listing (LIST) pada perusahaan perbankan di Indonesia tahun periode 2015-2018 adalah 13,566667 dengan standar deviasi 8,9505958. Dimana umur listing terendah adalah 1,0000 dan tertinggi adalah 36,0000. Nilai rata-rata

4) Capital Adequacy Ratio

Dari hasil pengujian statistik deskriptif rata-rata Capital Adequacy Ratio (CAR) pada perusahaan perbankan di Indonesia tahun periode 2015-2018 adalah 0,212405 dengan standar deviasi 0,0479586. Dimana Capital Adequacy Ratio (CAR) terendah adalah 0,1033 dan tertinggi adalah 0,3821 . Nilai rata-rata tersebut menunjukkan bahwa rata-rata perusahaan sampel dalam menyediakan dana yang digunakan untuk mengatasi kemungkinan resiko kerugian yaitu sebesar 21,24\%. Berdasarkan data tersebut rata-rata Capital Adequacy Ratio telah melewati batas aman (minimal 8\%), Jadi perusahaan sektor perbankan dianggap telah efektif dalam menjalankan tanggungjawabnya.

5) Non Performing Loan

Dari hasil pengujian statistik deskriptif rata-rata Non Performing Loan (NPL) pada perusahaan perbankan di Indonesia tahun periode 2015-2018 adalah 0,017994 dengan standar deviasi 0,0126186. Dimana Non Performing Loan (NPL) terendah adalah 0,0005 dan tertinggi adalah 0,0487. Nilai rata-rata tersebut menunjukkan bahwa rata-rata 
perusahaan sampel dalam menghadapi risiko kredit suatu perusahaan perbankan yaitu sebesar 1,74\%. Berdasarkan data tersebut rata-rata Non Performing Loan dapat dilihat nilai NPL tidak melewati 5\%, karena semakin tinggi nilai NPL (diatas 5\%), maka bank tersebut bias dikatakan tidak sehat.

6) Profitabilitas

Dari hasil pengujian statistik deskriptif rata-rata Profitabilias (PROF) pada perusahaan perbankan di Indonesia tahun periode penelitian 2015-2018 adalah 0,013040 dengan standar deviasi 0,0099013. Dimana Profitabilitas terendah adalah 0,0013 dan tertinggi adalah 0,0785.

\subsection{Pengujian Hipotesis}

\subsubsection{Uji Statistik $t$}

Uji statistik t pada dasarnya menunjukkan seberapa jauh pengaruh suatu variabel independen secara individual (parsial) dalam menerangkan variasi variabel dependen (Ghozali, 2011). Untuk dapat menginterprestasikan koefisien variabel independen, pada penelitian ini digunakan nilai unstandardized coefficient. Uji t dilihat dengan probabilitas nilai t atau signifikansi < 0,05 , maka dapat dikatakan bahwa terdapat pengaruh antara variabel bebas terhadap variabel terikat secara parsial.

\section{Hasil Uji T (Parsial)}

Coefficients $^{\mathbf{a}}$

\begin{tabular}{|l|r|r|r|r|r|}
\hline Model & \multicolumn{2}{|c|}{$\begin{array}{c}\text { Unstandardized } \\
\text { Coefficients }\end{array}$} & $\begin{array}{c}\text { Standardized } \\
\text { Coefficients }\end{array}$ & \multicolumn{1}{c|}{ T } & Sig. \\
\cline { 2 - 4 } & \multicolumn{1}{|c|}{ B } & Std. Error & \multicolumn{1}{|c|}{ Beta } & & \\
\hline (Constant) &,- 078 &, 116 & &,- 669 &, 505 \\
SIZE &, 013 &, 003 &, 286 & 3,729 &, 000 \\
LIST &, 001 &, 001 &, 159 & 2,211 &, 029 \\
lCAR &, 110 &, 110 &, 066 &, 998 &, 320 \\
NPL &, 361 &, 426 &, 053 &, 847 &, 399 \\
PROF &, 218 &, 530 &, 027 &, 411 &, 682 \\
Lag_y &, 560 &, 064 &, 558 & 8,753 &, 000 \\
\hline
\end{tabular}

a.

Dependent Variable: VDIS

Berdasarkan tabel diatas menunjukkan bahwa variabel yang dimasukkan kedalam model regresi, terlihat bahwa variabel Ukuran perusahaan (SIZE) dan Umur listing (LIST) memiliki pengaruh signifikan, sementara Capital Adequacy Ratio (CAR), Non Performing Loan (NPL) dan profitabilitas tidak memiliki pengaruh signifikan terhadap Pengungkapan Sukarela (VDIS). Hal ini dapat dilihat sebagai berikut :

1) Variabel ukuran perusahaan (SIZE) pada tabel 4.10 diperoleh nilai $t$ hitung 3,729> t tabel 1,65857 dan nilai sig $(0,000)<\alpha(0,05)$ serta nilai koefisien $\beta$ sebesar 0,013 dengan arah positif. Hal ini menunjukkan variabel ukuran perusahaan (SIZE) berpengaruh positif terhadap luas pengungkapan sukarela. Ukuran perusahaan menunjukkan besar kecilnya perusahaan yang terlihat dari modal yang ditanamkam, total aktiva yang dimiliki, atau total penjualan yang diperoleh. Implikasi bagi manjemen dan investor bahwa perusahaan besar memiliki biaya keagenan yang tinggi. Biaya keagenen ini dapat diminimalisir dengan adanya pengungkapan informasi yang lebih luas sebagai bentuk pertanggungjawaban manajemen kepada stakeholder.

2) Variabel umur listing (LIST) pada tabel 4.10 diperoleh nilai

$\mathrm{t}$ hitung 2,211 > t tabel 1,65857 dan nilai sig $(0,029)<\alpha(0,05)$ serta nilai koefisien $\beta$ sebesar 0,001 dengan arah positif. Hal ini menunjukkan variabel umur listing (LIST) berpengaruh positif terhadap luas pengungkapan sukarela. erusahaan yang sudah lama go public (listing di pasar modal), akan lebih dikenal oleh 
masyarakat. Implikasinya, investor menuntut manajemen untuk mengungkap informasi seluasluasnya.

3) Variabel capital adequacy ratio (CAR) pada tabel 4.10 diperoleh nilai $\quad t$ hitung $0,998>t$ tabel 1,65857 dan nilai sig $(0,320)<\alpha(0,05)$ serta nilai koefisien $\beta$ sebesar 0,110 dengan arah positif. Hal ini menunjukkan variabel capital adequacy ratio (CAR) tidak berpengaruh signifikan namun memiliki arah positif terhadap luas pengungkapan sukarela. Capital Adequacy Ratio (CAR) menunjukkan kemampuan manajemen bank untuk mengidentifikasi, mengukur, mengawasi dan mengontrol resiko yang dapat berpengaruh terhadap besarnya modal. Dengan melaporkan kinerja keuangan perusahaan salah satu cara untuk memuaskan para stakeholder, diharapkan para stakeholder akan memberikan lebih banyak dana (modal) bagi perusahaan. Hal ini menunjukkan dengan semakin besarnya dana yang dimiliki perusahaan, modal yang dimiliki oleh perusahaan untuk kegiatan dalam melakukan keterbukaan informasi perlu diperluas sebagi bentuk pertanggungjawaban manajemen kepada stakeholder.

4) Variabel non performing loan (NPL) pada tabel 4.10 diperoleh nilai $\quad t$ hitung 3,0,847 $>\mathrm{t}$ tabel 1,65857 dan nilai sig $(0,0,399)<\alpha(0,05)$ serta nilai koefisien $\beta$ sebesar 0,361 dengan arah positif. Hal ini menunjukkan variabel non performing loan (NPL) tidak berpengaruh signifikan namun memiliki arah positif terhadap luas pengungkapan sukarela. Perusahaan perbankan yang memiliki tingkat NPL yang rendah, tidak perlu menyediakan dana yang lebih banyak utuk menutupi kerugian bank yang diakibatkan karena adanya kredit macet (Non Performing Loan). Hal ini menunjukkan manajemen dan investor sudah merasa puas dengan kinerja yang bagus sehingga pengungkapan informasi sudah dianggap cukup tanpa harus diperluas lagi.

5) Variabel profitabilitas (PROF) pada tabel 4.10 diperoleh nilai t hitung $0,411>\mathrm{t}$ tabel 1,65857 dan nilai sig $(0,682)<\alpha(0,05)$ serta nilai koefisien $\beta$ sebesar 0,218 dengan arah positif. Hal ini menunjukkan variabel profitabilitas (PROF) tidak berpengaruh signifikan namun memiliki arah positif terhadap luas pengungkapan sukarela. Profitabilitas yang diukur dengan ROA menunjukkan prestasi manajemen yang menjadi indikator kinerja perusahaan yang dilihat dari laporan laporan keuangan. Semakin tinggi rasio ini menunjukkan kondisi perusahaan dalam keadaan baik dan stabil.

Sehingga dengan melihat hasil analisis data unstandardized coefficient pada tabel 4.10 maka diperoleh persamaan model regresi sebagai berikut:

VDIS = a + $\boldsymbol{\beta 1 S I Z E ~ + ~ \beta 2 L I S T ~ + ~ \beta 3 C A R ~ + ~ \beta 4 N P L ~ + ~ \beta 5 P R O F ~ + ~ e ~}$
$=-, 078+0,013$ SIZE+0,001LIST+0,110CAR+0,361NPL+0,218PROF+e

\subsubsection{Uji Koefisien Determinasi (Adjusted R2)}

Hasil Uji Koefisien Determinasi (Adjusted R2) Model Summary ${ }^{b}$

\begin{tabular}{|l|r|r|r|r|}
\hline Model & R & R Square & $\begin{array}{c}\text { Adjusted R } \\
\text { Square }\end{array}$ & $\begin{array}{r}\text { Std. Error of } \\
\text { the Estimate }\end{array}$ \\
\hline 1 &, $785^{\mathrm{a}}$ &, 616 &, 595 &, 05075 \\
\hline
\end{tabular}

a. Predictors: (Constant), Lag_y, NPL, PROF, CAR, LIST, SIZE

a. Dependent Variable: VDIS

Sumber : Data olahan SPSS

Berdasarkan tabel diatas terlihat bahwa hasil pengujian yang dilakukan besarnya nilai Adjusted $R$ Square pada model summary sebesar 0,595 atau 59,5\%. Hal ini berarti bahwa kemampuan variabel independen ukuran perusahaan (SIZE), Umur perusahaan (LIST), Capital Adequacy Ratio (CAR), Non 
Performing Loan (NPL) dan profitabilitas dalam menjelaskan variabel dependen (VDIS) sebesar $59,5 \%$, sedangkan sisanya $(100 \%-59,5 \%=40,5 \%)$ dijelaskan oleh variabel diluar model atau dijelaskan oleh faktor-faktor lain yang tidak dibahas dalam penelitian ini. Digunakannya angka Adjusted $R$ Square, karena dalam penelitian ini menggunakan lebih dari dua variabel independen.

\subsection{Pembahasan}

\subsubsection{Pengaruh Ukuran Perusahan Terhadap Pengungkapan Sukarela (Voluntary Disclosure)}

Hasil regresi yang ditunjukkan pada tabel 4.10 diperoleh hasil koefisien regresi untuk variabel Ukuran Perusahaan diperoleh nilai t hitung sebesar 3,729 dengan nilai signifikansi sebesar 0,000. Karena nilai signifikansi sebesar 0,000 lebih kecil dari 0,05 dan nilai t hitung 3,729 lebih besar dari nilai t tabel 1,65857. Sehingga dapat disimpulkan bahwa hipotesis persamaan (H1): Ukuran Perusahaan Berpengaruh Terhadap Tingkat Kelengkapan Pengungkapan Sukarela, diterima.

Dengan demikian dapat dinyatakan bahwa ukuran perusahaan berpengaruh positif dan signifikan terhadap tingkat pengungkapan sukarela pada laporan tahunan perusahaan dengan tingkat keyakinan 95\%. Hasil penelitian ini konsisten dengan hasil penelitian (Hidayat, 2017) yang menyimpulkan bahwa ukuran perusahaan berpengaruh poistif dan signifikan terhadap tingkat pengungkapan sukarela laporan tahunan perusahaan.

Alasan yang mendasari hasil penelitian adalah perusahaan besar cenderung memiliki biaya keagenan yang lebih besar karena semakin besar ukuran perusahaan, maka semakin meningkat pula jumlah stakeholder yang terlibat di dalamnya. Biaya keagenan dapat diminimalisasi dengan adanya pengungkapan informasi yang lebih memadai sebagai bentuk pertanggungjawaban manajemen. Selain itu, perusahaan besar memiliki kegiatan usaha yang lebih kompleks, sehingga menimbulkan dampak yang lebih besar bagi masyarakat dan lingkungan sekitarnya. Oleh karena itu, perusahaan besar dituntut untuk mengungkapkan informasi lebih luas sebagai bentuk pertanggung-jawabannya dari pada perusahaan kecil.

\subsubsection{Umur Listing Terhadap Pengungkapan Sukarela (Voluntary Disclosure)}

Hasil regresi yang ditunjukkan pada tabel 4.10 diperoleh hasil koefisien regresi untuk variabel Umur Perusahaan diperoleh nilai nilai t hitung sebesar 2,211 dengan nilai signifikansi sebesar 0,029. Karena nilai signifikansi sebesar 0,029 lebih kecil dari 0,05 dan nilai t hitung 2,211 lebih besar dari nilai t tabel 1,65857. Sehingga dapat disimpulkan bahwa hipotesis persamaan (H2): Umur Listing Berpengaruh Terhadap Tingkat Kelengkapan Pengungkapan Sukarela, diterima.

Dengan demikian maka data dinyatakan bahwa umur listing berpengaruh signifikan terhadap tingkat pengungkapan sukarela pada laporan tahunan perusahaan dengan tingkat keyakinan 95\%. Hasil penelitian ini konsisten dengan hasil penelitian Wahyuningsih (2016) yang menyimpulkan bahwa umur listing berpengaruh positif dan signifikan terhadap tingkat pengungkapan sukarela laporan tahunan perusahaan.

Alasan yang mendasari hasil penelitian ini adalah perkembangan teknologi dan informasi. Perusahaan dengan umur yang relatif muda namun telah difasilitasi dengan teknologi yang canggih, sehingga pengungkapan informasinya telah berkembang. Selain itu menurut, perusahaan yang telah lama listed di BEI maupun yang baru sama-sama ingin menarik perhatian para investor dengan mengungkapkan informasi laporan tahunan perusahaan mereka.

Perusahaan yang berumur lebih tua memiliki pengalaman yang lebih banyak dalam mempublikasikan laporan keuangan. Perusahaan yang memiliki pengalaman lebih banyak akan lebih mengetahui kebutuhan konstituennya akan informasi tentang perusahaan. pada reaksi pasar umur listing merupakan potensial determinant dari praktek pengungkapan tanggung jawab social perusahaan. Perusahaan yang telah lama berdiri dapat mencerminkan tingkat kedewasaan dari perusahaan tersebut. Semakin lama perusahaan terdaftar di Bursa Efek Indonesia, maka perusahaan tersebut semakin memberikan memberikan dampak terhadap keadaan lingkungan dan sosialnya. Hal 
ini tentu akan mendapatkan perhatian dari masyarakat luas. Secara umum, perusahaan yang telah lama melakukan usaha cenderung akan mengungkapan informasi social perusahaan lebih banyak dari pada perusahaan yang baru beroperasi. Hal ini akan membuat citra perusahaan menjadi baik dimata masyarakat luas. Jika perusahaan memiliki citra yang baik dimata masyarakat, maka hal ini akan mempengaruhi reaksi investor terhadap perusahaan tersebut.

Analisis untuk mendukung hasil penelitian ini adalah semakin lama umur listing terdaftar di Bursa Efek Indonesia, maka perusahaan tersebut lebih memahami informasi tambahan apa saja yang akan memancing reaksi secara positif dari investor. Sehingga manajemen akan memilih informasiinformasi yang dapat memancing perhatian investor dan memiliki pengaruh positif terhadap perusahaan. Dengan demikian perusahaan perlu mengungkapkan semua informasi yang dimilikinya.

\subsubsection{Capital Adequacy Ratio (CAR) Terhadap Tingkat Kelengkapan Pengungkapan Sukarela (Voluntary Disclosure)}

Hasil regresi yang ditunjukkan pada tabel 4.10 diperoleh hasil koefisien regresi untuk variabel Capital Adequacy Ratio diperoleh nilai t hitung sebesar 0,998 dengan nilai signifikansi sebesar 0,320. Karena nilai signifikansi 0,320 lebih besar dari 0,05 dan nilai t hitung 0,998 lebih kecil dari nilai $\mathrm{t}$ tabel 1,65857. Sehingga dapat disimpulkan bahwa hipotesis persamaan (H3): Capital Adequacy Ratio Berpengaruh Terhadap Tingkat Kelengkapan Pengungkapan Sukarela, ditolak.

Hasil Penelitian ini sejalan dengan Masrurroh (2017) yang menyatakan bahwa Capital Adequacy ratio (CAR) tidak berpengaruh positif signifikan. Dimana CAR merupakan rasio kecukupan modal pada bank yang pengungkapan sukarela tidak dapat mengubah besar kecil modal yang diperoleh bank, hal ini diduga karena bank pasti akan lebih fokus kepada nasabah dan pemegang saham. Kemudian modal tersebut lebih berpengaruh pada pembiayaan atau pemberian kredit atau biaya operasional bank tersebut, sehingga bank tidak begitu berfokus pada pengungkapan sukarela.

Selain itu, hal ini diduga karena pada awal menerapkan pengungkapan bank sudah siap dengan dana khusus untuk kegiatan pengungkapan, namun tahun selanjutnya kekuarangan modal untuk dialokasikan pada program pengungkapan. Seharusnya manajemen bank harus lebih kreatif lagi dalam menentukkan program untuk masyarakat supaya dalam mengungkapkan keterbukaan informasi di annual report dapat menarik para investor atau mitra untuk membantu program pengungkapan sukarela pada bank tersebut. Khususnya membantu dana untuk melancarkan program pengungkapan sukarela atau keterbukaan informasi.

\subsubsection{Non Performing Loan Terhadap Tingkat Kelengkapan Pengungkapan Sukarela (Voluntary Disclosure )}

Hasil regresi yang ditunjukkan pada tabel 4.10 diperoleh hasil koefisien regresi untuk variabel Non Performing Loan diperoleh nilai t hitung sebesar 0,847 dengan nilai signifikansi sebesar 0,399. Karena nilai signifikansi 0,399 lebih besar dari 0,05 dan nilai t hitung sebesar 0,847 lebih kecil dari nilai t tabel 1,65857. Sehingga dapat disimpulkan bahwa hipotesis persamaan (H4): Non Performing

\section{Loan Berpengaruh Terhadap Tingkat Kelengkapan Pengungkapan Sukarela, ditolak.}

Penelitian ini sejalan dengan penelitian yang dilakukan oleh Menurut Masrurroh (2017) semakin besar tingkat Non Performing Loan (NPL) maka menunjukkan bahwa bank tersebut tidak professional dalam pengelolaan kreditnya dan memberikan indikasi bahwa risiko atas pemberian kredit pada bank cukup searah dengan tingginya NPL yang dihadapi oeh bank. Dengan demikian, tinggi atau rendanya NPL tidak berpengaruh pada pengungkapan. Penerapan dan pengungkapan atau keterbukaan informasi bukan lagi sekedar kegiatan melainkan sebuah kewajiban bagi bank dalam menjaga kelangsungan hidupnya.

Maka, tinggi rendahnya NPL tidak menghalangi bank melakukan kegiatan pengungkapan karena memang sudah kewajiban bank untuk memperhatikan kondisi masyarakat di sekitar bank tersebut. Maka Non Performing Loan (NPL) pada bank tidak berpengaruh terhadap pengungkapan 
pengungkapan sukarela.

\subsubsection{Profitabilitas Berpengaruh Terhadap Tingkat Kelengkapan Pengungkapan Sukarela (Voluntary Disclosure)}

Hasil regresi yang ditunjukkan pada tabel 4.10 diperoleh hasil koefisien regresi untuk variabel profitabilitas diperoleh nilai t hitung sebesar 0,411 dengan nilai signifikansi sebesar 0,682. Karena nilai signifikan 0,682 lebih besar dari 0,05 dan nilai t hitung lebih kecil dari nilai t tabel 1,65857. Sehingga dapat disimpulkan bahwa hipotesis persamaan (H5) : Profitabilitas Berpengaruh

\section{Terhadap Tingkat Kelengkapan Pengungkapan Sukarela, ditolak.}

Dengan demikian maka data dinyatakan bahwa profitabilitas tidak berpengaruh signifikan terhadap tingkat pengungkapan sukarela pada laporan tahunan perusahaan dengan tingkat keyakinan 95\%. Hasil penelitian ini konsisten dengan hasil penelitian Alfiana (2018), yang menyimpulkan bahwa profitabilitas tidak berpengaruh signifikan terhadap tingkat pengungkapan sukarela laporan tahunan perusahaan.

Hasil dari pengujian terlihat bahwa profitabilitas tidak berpengaruh terhadap luas pengungkapan sukarela yang dilakukan perusahaan. oleh karena itu berarti dapat disimpulkan profitabilitas tidak berpengaruh terhadap tindakan luas pengungkapan sukarela yang dilakukan perusahaan profitabilitas tidak berpengaruh terhadap luas pengungkapan sukarela di lihat dari hasil pengujian hipotesis menunjukkan arah yang positif. Tidak berpengaruhnya terhadap tindakan luas pengungkapan sukarela, hal ini dikarenakan walaupun profitabilitas cenderung menjadi perhatian para investor dan kreditor, namun profitabilitas yang tinggi tidak menjamin semakin luasnya pengungkapan sukarela disajikan, yang mendasari hal tersebut adalah karena perusahaan memiliki pandangan bahwa informasi yang menggambarkan kemampuan financial perusahaan cenderung memiliki daya tarik yang lebih tinggi sehingga pengungkapan sukarela dianggap tidak terlalu mempengaruhi keputusan para investor maupun kreditor.

Alasan bahwa perusahaan beranggapan bahwa informasi yang menggambarkan kemampuan financial dapat mencakup seluruh informasi yang dibutuhkan stakeholder dibandingkan dengan jenis informasi yang lainnya. Hal ini menyebabkan perusahaan merasa tidak perlu melakukan pengungkapan informasi yang bersifat sukarela.

Hasil yang tidak konsisten dengan penelitian Wardani (2012) yang menyatakan profitabilitas berpengaruh terhadap luas pengungkapan sukarela. Hal tersebut dikarenakan semakin tinggi profitabilitas perusahaan maka semakin luas pengungkapan sukarelanya begitu pula sebaliknya karena semakin tinggi profitabilitas maka kelangsungan usahanya semakin terjaga.

Penelitian ini mengindikasikan bahwa semakin banyak laba yang dimiliki oleh perusahaan, maka semakin banyak pula informasi sukarela yang diungkapkan dalam laporan tahunan. Kondisi ini didasarkan pada alasan bahwa profitabilitas yang tinggi berhubungan dengan kondisi good news suatu perusahaan, sehingga manajemen terdorong untuk melakukan pengungkapan sukarela secara lebih luas untuk membantu menyebarkan good news.

\section{PENUTUP}

\subsection{Kesimpulan}

Penelitian ini bertujuan untuk menganalisis pengaruh karakteristik perusahaan dan profitabilitas terhadap tingkat kelengkapan pengungkapan sukarela dalam laporan tahunan pada perusahaan perbankan yang telah terdaftar di Bursa Efek Indonesia periode tahun 2015-2018. Analisis dilakukan dengan menggunakan analisis regresi berganda dengan program Statistical Package for Social Science (SPSS) IBM versi 21. Periode pengamatan dalam penelitian ini adalah tahun 2015-2018 dan menggunakan 30 perusahaan terpilih berdasarkan purposive sampling dengan total keseluruhan sebanyak 120 sampel selama 4 tahun yang menerbitkan laporan tahunan selama periode tersebut. Berdasarkan hasil analisis dan pengujian hipotesis dapat dibuat kesimpulan sebagai berikut: 
1. Hasil penelitian ini memberikan konfirmasi empiris bahwa ukuran perusahaan yang dilihat dari total aset berpengaruh positif dan signifikan terhadap tingkat pengungkapan sukarela pada laporan tahunan.

2. Hasil penelitian ini memberikan konfirmasi empiris bahwa umur listing berpengaruh positif dan signifikan terhadap tingkat pengungkapan sukarela pada laporan tahunan.

3. Hasil penelitian ini memberikan konfirmasi empiris bahwa Capital Adequacy Ratio (CAR) tidak berpengaruh signifikan terhadap tingkat pengungkapan sukarela pada laporan tahunan perbankan.

4. Hasil penelitian ini memberikan konfirmasi empiris bahwa Non Performing Loan (NPL) tidak berpengaruh signifikan terhadap tingkat pengungkapan sukarela pada laporan tahunan perusahaan.

5. Hasil penelitian ini memberikan konfirmasi empiris bahwa profitabilitas yang diukur dengan ROA tidak berpengaruh terhadap tingkat pengungkapan sukarela pada laporan tahunan perusahaan.

\subsection{Keterbatasan}

Penelitian ini memiliki keterbatasan yaitu sampel penelitian yang hanya mencakup perusahaan perbankan yang berjumlah 30 perusahaan akibat adanya pembatasan kriteria perusahaan. Terbatasnya variabel independen yang diteliti yaitu ukuran perusahaan, umur listing, Capital Adequacy Ratio (CAR), Non Performing Loan (NPL) dan profitabilitas, serta periode pengamatan yang singkat. Selain itu, adanya unsur subjektif dalam mengukur tingkat pengungkapan sukarela yang hasilnya kemungkinan akan berbeda antara peneliti yang satu dengan peneliti lainnya.

\subsection{Saran}

Berdasarkan hasil penelitian serta hal-hal yang terkait dengan keterbatasan penelitian maka peneliti selanjutnya disarankan tidak hanya terbatas pada perusahaan perbankan saja, melainkan sektor industri lain yang terdaftar di Bursa Efek Indonesia. Selain itu juga diharapkan untuk menambah beberapa variabel independen yang memiliki variasi dan potensi yang erat kaitannya dengan tingkat pengungkapan sukarela, serta memperpanjang tahun penelitian sehingga dapat memberikan hasil yang mendekati kondisi yang sebenarnya. 


\section{DAFTAR PUSTAKA}

Agustina, L. (2012). Pengaruh Karakteristik Perusahaan Terhadap Pengungkapan Laporan Tahunan. Jurnal Dinamika AKuntans, Vol 15, No. 1, 70-82.

Alfiana, Yeni. (2018) Pengaruh Profitabilitas, Leverage, Proporsi Dewan Komisaris, Ukuran KAP dan Ukuran Perusahaan Terhadap Luas Pengungkapan Informasi Sukarela Laporan Keuangan Tahunan Perusahaan Sektor Keuangan Yang Terdaftar di Bursa Efek Indonesia. Jurnal Manajemen dan Bisnis Sriwijaya. Vol. 16 (1).

Anindita, M. Y. K. P. (2013). Pengaruh Ukuran Perusahaan, Profitabilitas Dan Tipe Industri Terhadap Pengungkapan Sukarela Pelaporan Keberlanjutan. E-Journal Uajy.Vol 5, No 2, 2460-0585.

Dendawijaya, A. (2012). Pengaruh Karakteristik Perusahaan Terhadap Luas Pengungkapan Kegiatan Corporate Social Responsibility.Jurnal Akuntansi. Vol 2. No. 1.

Ghozali, I. (2013). Aplikasi Analisis Multivariate Dengan Program IBM dan SPSS. In aplikasi analisis multivariate dengan program ibm spss 19. https://doi.org/10.2307/1579941

Hardiningsih, P. (2008). Anaisis Faktor-faktor yang Mempengaruhi Voluntary Disclosure Laporan Tahunan Perusahaan. Jurnal Bisnis Dan Ekonomi (JBE), 15(1), 67-79.

Herawati, Edy Suwito, A. (2005). Analisis Pengaruh Karakteristik Perusahaan Terhadap Tindakan Perataan Laba yang Dilakukan oleh Perusahaan yang Terdaftar di Bursa Efek Jakarta. Simposium Nasional Akuntansi XVI.

Hidayat M. (2017). Faktor-Faktor Yang Mempengaruhi Pengungkapan Sukarela Pada Laporan Tahunan Sektor Perbankan Di Bursa Efek Indonesia. Jurnal Dimensi Akuntansi, Vol. 6, No. 1: 151-172. ISSN : 2085-9996.

Liana, L. (2009). Penggunaan MRA dengan Spss untuk Menguji Pengaruh Variabel Moderating terhadap Hubungan antara Variabel Independen dan Variabel Dependen. Jurnal Teknologi Informasi DINAMIK, Vol 10, No. 1, Maret.

Murni, Y. (2016). pengaruh Karakteristik Perusahaan dan Profitabilitas Terhadap Tingkat Kelengkapan Pengungkapan Sukarela dalam Laporan Tahunan Perbankan di Indonesia. Simposium Nasional Akuntansi XIX.

Nuryaman. (2009). Pengaruh Konsentrasi Kepemilikan, Ukuran Perusahaan, dan Mekanisme Corporate Governance Terhadap Pengungkapan Sukarela. Jurnal Akutansi Dan Keuangan Indonesia. Vol 7, No.3,September, 351-366.

Sembiring, E. R. (2005). Karakteristik Perusahaan Dan Pengungkapan Tanggung Jawab Sosial : Study Empiris Pada Perusahaan Yang Tercatat Di Bursa Efek Jakarta. Simposium Nasional Akuntansi XVI.

Sudarmadji, A. M., \& Sularto, L. (2007). Pengaruh Ukuran Perusahaan, Profitabilitas, Leverage, dan Tipe Kepemilikan Perusahaan terhadap Luas Voluntary Disclosure laporan Keuangan Tahunan. Proceeding PESAT(Psikologi, Ekonomi, Sastra, Arsitek \& Sipil), 31 (1-3),405440.

Suripto, B. (1999). Pengaruh Karakteristik Perusahaan terhadap Luas Pengungkapan Sukarela dalam Laporan Keuangan Tahunan. Simposium Nasional Akuntansi II.

Suryani, A. W. 2007. Analisis Pengaruh Faktor Fundamental Terhadap Harga Saham pada parusahaan LQ45 di Bursa Efek Jakarta Tahun 2003-2005. Jurnal EMAS Vol 1 No. 1, 1-12.

Suta, M. (2012). Pengaruh Karakteristik Perusahaan Terhadap Pengungkapan dalam Annual Report. Jurnal Akuntansi dan Keuangan Indonesia. Vol 15 No.1, 5-7

Wardani, R. P. (2012). Faktor-faktor yang Mempengaruhi Luas Pengungkapan Sukarela. Jurnal Akuntansi Dan Keuangan. 31 (1-3), 405-440. 
Wardani, R. P. (2013). Faktor-Faktor yang Mempengaruhi Luas Pengungkapan Sukarela. Jurnal Akuntansi Dan Keuangan. Vol. 3, No. 4, pp. 305-360.

Widianto, H. S. (2011). Pengaruh Profitabilitas, Likuiditas, Leverage, Aktivitas, Ukuran Perusahaan, Dan Corporate Governance Terhadap Praktik Pengungkapan Sustainability Report. Proceeding Simposium Nasional Akuntansi XIV. 